\title{
"Não sou professor, não sou advogado, sou jornalista!"
}

Heródoto Barbeiro é graduado em Direito, História e Jornalismo. Foi professor de História em escolas públicas e particulares, trabalhou em cursinhos preparatórios para vestibular e é autor de diversos livros, mas como ele mesmo nos disse em entrevista realizada na Rede Globo, logo depois de seu programa diário na rádio CBN, considerase apenas um jornalista. Além dessa presença diária no rádio, ele ancora o telejornal da TV Cultura todas as noites. Escreveu, também, manuais de jornalismo para o rádio e a TV. Figura conhecida e respeitada, está presente em muitos eventos e campanhas que lutam pela informação do público e por uma visão ética e humanista dos meios de comunicação.

Tudo isso já seria suficiente para que nós o entrevistássemos para a revista Comunicação \& Educação. Contudo, uma razão a mais pesou em nossa decisão - de acordo com nossas pesquisas, seu nome é um dos mais lembrados pelos professores sempre que se aborda a credibilidade possível nos meios de comunicação de massa. Assim, aqui está a entrevista que ele nos concedeu e na qual fala de sua carreira e das relações necessárias entre comunicação e educação.

Por Maria Cristina Castilho Costa

C \& E: Heródoto, você foi professor e autor de livro didático. Como chegou ao rádio e à televisão?

Heródoto: Essa não foi minha primeira opção de carreira... eu imaginava ser professor de História e advogado. Como professor, trabalhei uns vinte e cinco anos, dei aulas em muitos lugares. Foram dezesseis anos só em cursinhos, como o Objetivo, entre outros. Dei aulas por doze anos na USP, onde pensei que iria fazer carreira como professor. Mas acabei descobrindo o jornalismo, acidentalmente, quando dava aulas de História Contemporânea no cursinho... Um belo dia, num mês de julho, aparece por lá um equipamento de televisão para transmissão de aulas de telecurso. Então, propus: "Por que a gente não aproveita e não faz um jornal para alunos? Eu sou professor de História Contemporânea e posso fazer um telejornal”. Comecei a fazer um jornal interno com duração de vinte minutos, no qual comentava as notícias do dia. Isso me deu uma pequena experiência que foi importante no ano seguinte, quando começou o Telecurso Segundo Grau e eu cheguei a gravar 30 horas de aulas 
de História do Brasil. A cada dia, eu aprendia um pouco mais. Quando a TV Gazeta precisou de uma pessoa que apresentasse um programa noturno chamado Show de ensino, com notícias e comentários teóricos, alguém indicou meu nome. Comecei a trabalhar na TV Gazeta fazendo um programa semanal. Até então, não tinha passado pela minha cabeça cursar jornalismo. Mais tarde, fui convidado a fazer um teste para comentarista de assuntos internacionais na rádio Jovem Pan. Passei no teste e eles me aceitaram. Ter sido professor de História foi um bom começo, pois me deu condições para comentar as notícias que eu veiculava. Entretanto, como se exige formação de pelo menos dois terços dos profissionais atuantes nos meios de comunicação, resolvi entrar para o curso da Cásper Líbero. Lá, tive a felicidade de conviver com muitos colegas jornalistas experientes que, pela mesma razão, haviam procurado a faculdade em busca de diploma. Eram pessoas como Carlos Costa, editor-chefe da Playboy, e Maria Adelaide Amaral, que foi minha colega de sala de aula... Várias pessoas que hoje desempenham importantes funções na mídia. Tive a oportunidade de fazer um verdadeiro curso de "imersão", convivendo entre pessoas com muito a ensinar. Por outro lado, vários deles haviam sido meus alunos no cursinho. Tudo isso, para mim, foi uma revolução - depois de quinze anos de aulas, deixar de ser professor e voltar a ser aluno e me colocar na condição de aluno. Essa imersão no jornalismo me fez perceber que, em vez de usar os verbos no passado, como até então me acostumara, eu passei a usar os verbos no presente. Eu, que sempre tivera a disciplina necessária a um professor com muitas aulas para dar, passei a viver num mundo sem rotina, no qual se sabe como o dia começa, mas não como termina. Isso foi de tal forma me apaixonando, me encantando, que eu parei de ser professor e, hoje, quando as pessoas me perguntam, eu digo: "Sou jornalista. Não sou professor, não sou advogado. Sou só jornalista, porque nós somos aquilo que nós fazemos”.

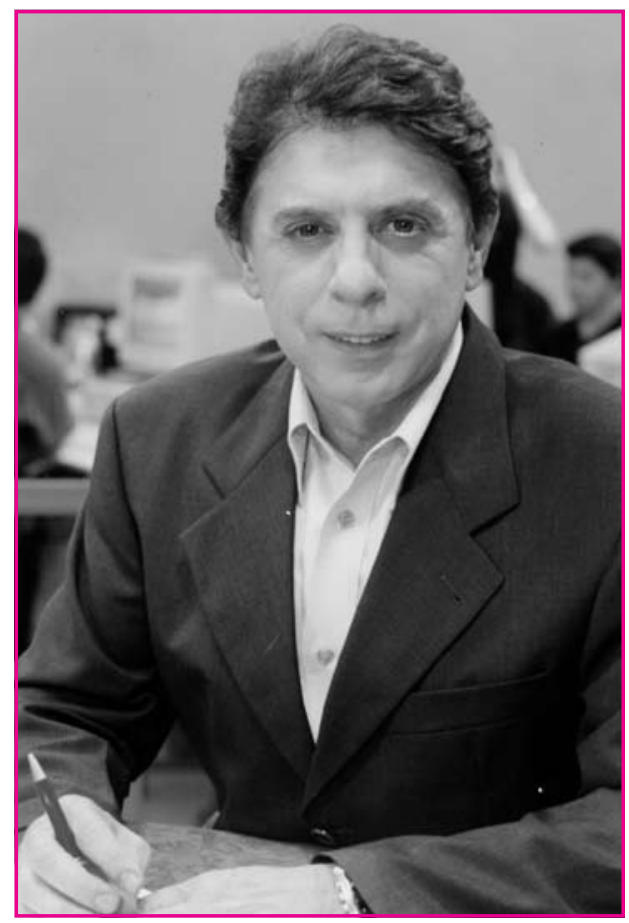

Heródoto: "Somos aquilo que nós fazemos".

C \& E: Como você explica a resistência dos educadores em trabalhar com esses verbos no presente, em trabalhar com o dia-a-dia do aluno?

Heródoto: Acho que isso tem origem na ditadura militar. Eu era professor, fiz parte do movimento estudantil, e acho que essa atitude é resultado da ditadura militar no País. Dos nossos quinhentos anos de história, não tivemos nem cinqüenta de liberdade democrática. Vivemos agora vinte e cinco anos de 
redemocratização. Liberdade de imprensa no País, muito pouca; de expressão, quase nada. Sempre dei aula de atualidades num tempo de ditadura, e o que acontecia? Tínhamos medo de falar de nossa época. Quando chegávamos aos acontecimentos de 1945, 1950, à ditadura Vargas, parávamos com medo de ser presos... Nós contribuímos para que esta geração que hoje dá aula não tivesse, na escola, um conhecimento científico e crítico da atualidade brasileira. Somos os responsáveis, eu e minha geração. Este é o primeiro ponto. O segundo ponto é o seguinte: quando se introduz a imprensa em sala de aula, corre-se o risco de falar coisas com as quais as pessoas não concordam, nem o dono da escola nem os pais dos alunos. Nem sempre há espaço para a crítica e para a dissidência. Quando trabalhava numa escola particular, o Pueri Domus, fui candidato a presidente do sindicato dos professores pela chapa de oposição. Perdi a eleição e o meu emprego, pois não tinha o apoio do sindicato patronal. Foi nessa escola também onde, pela primeira vez, adotei o jornal como material didático para as aulas de Estudos de Problemas Brasileiros. A coordenação estranhou: "Como jornal? Então o curso vai ser dado a partir do jornal?”. Eu sempre dizia que quem quisesse entender história tinha que ler jornal, pois se não compreendemos o que acontece à nossa volta, como podemos entender o passado? Há uma forte ligação entre o passado e o presente. Mas o reconhecimento acabou por vir. Em um encontro anual com os pais dos alunos, quando lhes perguntei: "O que o senhor acha de seu filho estar lendo jornal?", muitos se mostraram satisfeitos. Algumas vezes, eu pedia aos alunos que entrevistassem a família a respeito das notícias e das informações que o jornal trazia. Qual é o pai que não gosta de chegar em casa e ouvir o filho dizer: "Pai, o que aconteceu hoje no país? Preciso entrevistar você sobre assuntos da atualidade"?

Como se vê, o jornalismo é um instrumento didático que pode ajudar o aluno a entender sua história - para o bem e para o mal.

C \& E: Você acha que o autoritarismo é um dos responsáveis pela resistência do professor em usar a mídia nas atividades escolares?

Heródoto: $\mathrm{O}$ autoritarismo e as condições em que ele deixou a educação, que acabaram por confundir o professor. Hoje, quando os professores se referem à mídia, eles estão pensando preferencialmente em televisão, enquanto eu, quando me referia à mídia, pensava antes de tudo na imprensa, não na televisão. Os tempos são outros. De qualquer maneira, o professorado precisa ter uma posição crítica diante da mídia, seja a imprensa, seja a televisão.

C \& E: Heródoto, a mídia educa?

Heródoto: A mídia ajuda a educar quando não é só o reflexo de seu tempo, mas também a reflexão sobre ele. Por exemplo, se informarmos que o Papa, adoentado, voltou a ser internado no hospital, podemos causar algum impacto. Mas, se fizermos um retrospecto, evocando a importância do Papa no mundo e as conseqüências que sua doença ou morte terão na vida das pessoas, o impacto será muito maior. Assim, informando e ajudando a refletir, a mídia ajuda a educar, sim. 
C \& E: Pesquisas indicam que a maior parte do tempo que os professores dedicam à mídia é em busca de informação, e não de entretenimento. Pode-se dizer que a mídia é uma boa fonte de pesquisa para o professor?

Heródoto: É uma boa fonte, mas não deve ser a única. Ninguém pode se informar por uma única mídia; deve-se buscar vários canais simultaneamente. Não podemos dizer: "Eu assisto ao Jornal Nacional todas as noites e é o suficiente". Não, temos que ver o Jornal Nacional, ler a Folha de S. Paulo, O Globo, o Estadão, e assim por diante. Cada jornalista ou meio de comunicação faz um recorte diferente da realidade e, recorrendo a diferentes fontes, podemos formar uma idéia mais consistente sobre os fatos. Devemos sempre lançar mão de uma pluralidade de fontes.

C \& E: É possivel, através da escola, formar um cidadão mais crítico e um público mais informado?

Heródoto: A mídia é um reflexo da sociedade e, assim, pode ser ruim ou boa, mais crítica ou menos crítica, refletindo a sociedade em que atua. A mídia não condiciona a sociedade, o que existe é uma interação profunda entre ela e o meio circundante. Nessa interação percebe-se, muitas vezes, uma enorme pressão da sociedade sobre os meios de comunicação. Por exemplo, faço um telejornal às 9 horas da noite que dá um a dois pontos de Ibope. Meu concorrente indireto é o Ratinho, que dá 14 a 15 pontos de Ibope. Isso não é resultado de uma pressão dos meios de comunicação, mas daquilo que as pessoas querem ver, do mundo em que vivem. Elas têm opção. Podem escolher tanto entre esses programas como optar pela TV Câmara, pela TV Senado, que hoje são verdadeiras janelas que se abrem para o parlamento. Há muitas opções que podem ser úteis aos educadores... tudo dependerá da escolha que fizerem e de como trabalharão com as informações.

C \& E: Em termos de informação, de educação, que diferença há entre o rádio e a televisão?

Heródoto: Na verdade, eles são complementares. Como as mídias possuem características diferentes, elas têm uma forma diversa de transmitir a mesma mensagem. Se, ao ir para o trabalho, ficamos sabendo que houve um ataque contra o World Trade Center, a primeira coisa que fazemos ao chegar é ligar a televisão ou o computador para obter mais informações. Depois, lemos o jornal para nos aprofundarmos. Esse coquetel de mídia, essa confluência de meios de comunicação é fundamental para desenvolver o espírito crítico das pessoas.

C \& E: A internet é apontada como o veículo que mais transmite informações. O que você acha da internet para a educação e para a pesquisa?

Heródoto: Quando eu dava aulas sobre a Grécia, percebia que os alunos nem sequer sabiam onde ela se localizava. E não adiantava pedir que pesquisassem a respeito, pois eles apenas xerocavam o mapa e me entregavam. Eu continuava com a certeza de que eles não sabiam onde ficava Atenas, nem qual era a influência do relevo na civilização helênica, pois apenas haviam xerocado o 
mapa. Hoje, as pessoas acessam a internet, mas, da mesma forma, apenas colam e copiam, realizando um trabalho mecânico. Essa é a parte ruim da internet. Qual é a parte boa? Se quiserem ler, informar-se sobre o mundo inteiro, há conteúdo à disposição. Quando eu fiz meu trabalho de mestrado, tive que viajar a Portugal para consultar documentos que só havia nas bibliotecas. Hoje, se eu quiser ler os mesmos documentos, posso acessá-los pela internet. A possibilidade desse veículo é extraordinária. Tenho um amigo biólogo que diz não conseguir ler todos os artigos que estão disponíveis, na internet, sobre o assunto no qual se especializou. Imagine o impacto disso na difusão do conhecimento no mundo? Minha opinião é a seguinte: todas as mídias se integrarão nessa máquina chamada computador, de tal forma que não saberemos mais por qual nome chamá-las.

C \& E: Como você justifica sua popularidade entre os professores?

Heródoto: Eu já fui professor. Tive a sorte de ser professor de História e haver conseguido me valer de um raciocínio histórico muito útil ao jornalismo e que, muitas vezes, as faculdades de jornalismo não propiciam. Não basta dar nome, fatos e datas sobre um determinado acontecimento. É preciso desenvolver uma análise histórica e sociológica sobre os fatos. Tive a sorte de trazer isso na minha bagagem.

C \& E: Em termos da formação do profissional de mídia, podemos dizer que, cada vez mais, valoriza-se a prontidão técnica?

Heródoto: As escolas de jornalismo, especialmente as particulares, apresentam essa tendência. Elas relegam o que é realmente importante a um plano secundário - a ética, a postura política, a formação intelectual. Tudo isso fica num segundo plano. Eu atendo muitos alunos de jornalismo e os ajudo a pesquisar. Percebo, então, que eles não chegam ao âmago das questões. Se fizermos um levantamento entre os profissionais do meio, vamos ver que aqueles que sempre deram mais importância ao esforço de reflexão estão fora desse jornalismo que vem se tornando cada vez mais industrial.

C \& E: Os programas estão investindo muito na interatividade: receber e-mail, fax, enfim, uma série de movimentos em direção do receptor. Isso tem contribuído para melhor sintonia da mídia com o público ou esses recursos são encarados apenas como uma nova forma de entretenimento?

Heródoto: Com esses recursos, abre-se espaço para conhecer melhor quem está do outro lado da linha e também para fazer e receber críticas. Eu recebo muitas críticas, tanto na CBN como na TV Cultura, às quais respondo sempre: “Obrigado pela sua crítica, atenciosamente, Heródoto Barbeiro”. Não respondo à crítica porque as pessoas têm o direito de me julgar e de me criticar, na medida em que desempenho uma atividade pública e, pretensamente, represento uma parte da opinião pública. Recentemente, colocaram um ombudsman na Cultura, a cujas críticas respondo da mesma forma. Faço isso porque respeito 
mesmo quem me critica e aprendo com elas. Isso ajuda muito e demonstra que a interatividade é um canal de comunicação importante que não existia no passado.

C \& E: A internet e as mídias digitais representam a possibilidade de expressão para muitas pessoas?

Heródoto: Sim, porque não se depende mais da concessão do Estado para se ter um jornal, uma rádio ou uma TV. Li, ontem, uma informação que me surpreendeu: no ano passado foram vendidos, no Brasil, 3.400 milhões de novos computadores. Além disso, temos que considerar que o acesso à internet é cada vez mais wireless, ou seja, independente de cabos ou fios. Isso tudo vai ajudar a democratização da informação, rompendo com o paradigma de uma comunicação com poucos emissores e muitos receptores. A internet está promovendo uma capilarização na emissão. Assim, se não houver espaço institucional para transmitir uma idéia ou uma notícia, pode-se recorrer à internet, divulgar para a rede de amigos pessoais e pedir para que eles reproduzam para os seus conhecidos. Isso provocará uma ruptura no paradigma da comunicação.

Resumo: Nesta entrevista, o jornalista Heródoto Barbeiro, um dos nomes mais lembrados entre professores quando se aborda a questão da credibilidade possível nos meios de comunicação de massa, fala de sua carreira e das relações necessárias entre comunicação e educação. Discute também a prática jornalística, que valoriza a produção de notícias e negligencia o processo de reflexão sobre os fatos. Analisa ainda a utilização de mensagens dos meios de comunicação de massa, especialmente as veiculadas pelo jornal impresso, como instrumento didático de apoio ao conteúdo curricular desenvolvido em sala de aula. Nesse sentido, a mídia pode ser entendida como parceira da educação, desde que o processo seja compartilhado e desdobrado por meio de leituras mais complexas e articuladas, superando a redução estrutural de nomes, fatos e datas sobre um determinado acontecimento para construir uma interpretação sociológica relativa à realidade.

Palavras-chave: comunicação, educação, cultura, mídia, perfil.
Abstract: In this interview, the journalist Heródoto Barbeiro, one of the most remembered names when teachers refer to the issue of the credibility possible in mass media, talks on his career and the necessary relations between communication and education. He discusses the journalistic practice, which valorizes the news production and neglects the process of reflection on facts. Also analyzes the use of the mass media messages, particularly the ones brought by newspapers, as a didactic tool to support the curricular content developed in classroom. In this sense, media can be understood as an education partner since the process can be shared and extended by more complexes and articulated readings, surpassing the structural reduction of names, facts and dates on a determined event to build a sociological interpretation on reality.

Keywords: communication, education, culture, media, profile. 